
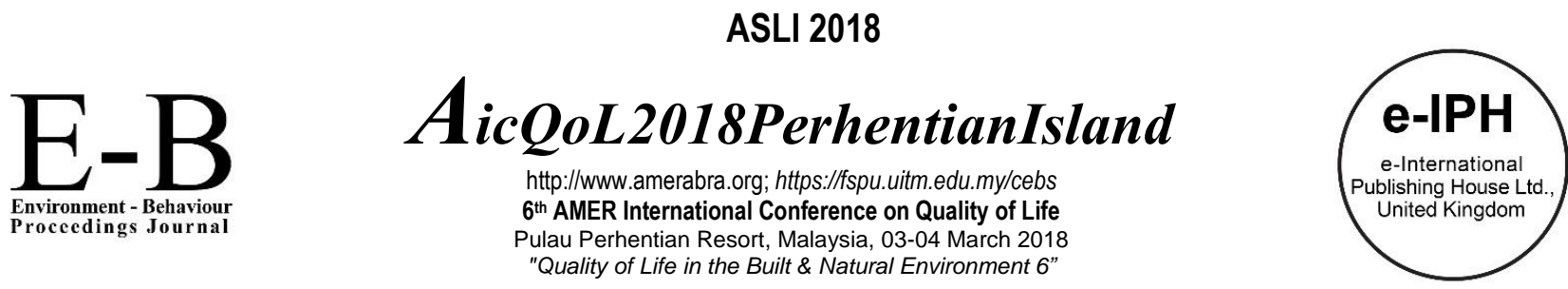

\title{
Internationalisation of Hospitals in the Wake of Green Agenda: How much more to be done?
}

\author{
Nuraisyah Chua Abdullah¹, Herwina Rosnan², Norzayana Yusof 3 \\ ${ }^{1}$ Faculty of Law, Universiti Teknologi MARA (UiTM), 40450. Shah Alam, Selangor. MALAYSIA \\ ${ }^{2}$ Arshad Ayub Graduate Business School, Universiti Teknologi MARA (UiTM). 40450. Shah Alam. Selangor. MALAYSIA \\ ${ }^{3}$ Faculty of Business and Management, Universiti Teknologi MARA (UiTM). 40450. Shah Alam. Selangor. MALAYSIA \\ nuraisyahc@yahoo.com / nuraisyah@salam.uitm.edu.my; herwina@salam.uitm.edu.my; norzayana.yusof@yahoo.com \\ Tel: +60 19-648 8348
}

\begin{abstract}
Despite striving to save the society from environmentally-related diseases, hospitals contribute to adverse environmental impacts. Green hospitals encourage public health through continuous reduction of its impact on the environment and the consequent burden of diseases. The concept strongly associates human health and the environment through green hospitals operations, governance and strategy. This paper examines the green environment policy and practice in the Malaysian medical hospital framework in comparison with selected countries and provides suggestions for the betterment of the green agenda and practices to improve the hospitals' internationalisation performance, hence uplifting the quality of life of affected parties.
\end{abstract}

Keywords: Green Environment Policy; Green Healthcare; Internationalisation; Healthcare

eISSN: 2398-42870 2018. The Authors. Published for AMER ABRA CE-Bs by e-International Publishing House, Ltd.. UK. This is an open access article under the CC BYNC-ND license (http://creativecommons.org/licenses/by-nc-nd/4.0). Peer-review under responsibility of AMER (Association of Malaysian Environment-Behaviour Researchers), ABRA (Association of Behavioural Researchers on Asians) and cE-Bs (Centre for Environment-Behaviour Studies), Faculty of Architecture, Planning \& Surveying, Universiti Teknologi MARA, Malaysia.

DOI: https://doi.org/10.21834/e-bpj.v3i7.1312

\subsection{Introduction}

Healthcare internationalisation started when people travel across country borders for health care such as spas and thermal bath. Today, health travellers traverse beyond their home country to seek invasive healthcare treatments. Meanwhile, the phenomena of hospital internationalising their services either by opening new branches in overseas, having a joint-venture (JV) agreement with international companies in foreign lands or by calling for international patients into Malaysia to undergo their healthcare services are expanding locally and at internal level. The term 'medical tourism' echoes to the internationalisation of hospitals in which runs indirect export as the services are intangible and location-bound, as opposed to direct exports as run by manufacturing firms. Malaysian medical tourism industry is supervised by the Malaysian Healthcare Travel Council (MHTC) whose members are mainly accredited private hospitals, specialist clinics and dental, and health centres. Malaysia has received numerous international awards including Destination of the Year (2015-2017).

Despite the conquest, issues of externalities caused by this business activity are imminent, though unpremeditated, thus jeopardising the sustainability of the healthcare sector. This is supported by the World Health Organisation (2015) as $15 \%$ of the total amount of waste generated by healthcare activities is considered hazardous material that may be infectious, toxic or radioactive. While data on Malaysian hospitals energy consumption is scarce, a 2011 case study on Hospital University Kebangsaan Malaysia (HUKM)'s Building Energy Index (BEI) recorded that the property enormously consumed $245 \mathrm{kWh} / \mathrm{m} 2$ energy per year as opposed to the Malaysian standard MS 1525:2001 of only $130 \mathrm{kWh} / \mathrm{m} 2$ per year for non-residential building $(\mathrm{Ng}, 2016)$. This calls for a need to leverage the green concept

eISSN: 2398-4287@ 2018. The Authors. Published for AMER ABRA cE-Bs by e-International Publishing House, Ltd., UK. This is an open access article under the CC BYNC-ND license (http://creativecommons.org/licenses/by-nc-nd/4.0/. Peer-review under responsibility of AMER (Association of Malaysian Environment-Behaviour Researchers), ABRA (Association of Behavioural Researchers on Asians) and cE-Bs (Centre for Environment-Behaviour Studies), Faculty of Architecture, Planning \& Surveying, Universiti Teknologi MARA, Malaysia.

DOI: https://doi.org/10.21834/e-bpj.v3i7.1312 
into hospitals settings because they lead in the primary sources of healthcare waste along with laboratories and research centres, mortuary and autopsy centres, animal research and testing laboratories (World Health Organisation, 2015). This paper examines the green environment policy and practice in the Malaysian medical hospital framework in comparison with selected countries and subsequently provides suggestions for the betterment of the green agenda and practices to improve the hospitals' internationalisation performance to upgrade the quality of life of the affected parties.

\subsection{Literature Review}

As green is no longer just about planting trees, all phases of constructing hospitals should be inclusive of the measurement tools. The green rating tools for Malaysia is managed by the Green Building Index (GBI) which was established in August 2008 by the Association of Architects Malaysia (PAM) that exclusively caters for buildings in a tropical climate (Bahaudin, Elias, \& Saifudin, 2014). Hence, Green Building Index (2015) has outlined the six criteria of Malaysian hospitals green rating through the Non-Residential New Construction (NRNC): Hospitals 2015, namely i) Energy Efficiency; ii) Indoor Environment Quality; iii) Sustainable Site Planning; iv) Sustainable Management; v) Materials, Resources, Water Efficiency; vi) Innovation. Accordingly, Energy Efficiency concerns the Design; Commissioning; and Verification and Maintenance criteria. On the other hand, Indoor Environmental Quality stresses on Air Quality; Thermal Comfort, Lighting, Visual, Acoustic Comfort; and Verification. Additionally, Sustainable Site Planning \& Management looks into Site Planning; Construction Management; Transportation; and Design. Further, Materials and Resources concerns Reused \& Recycled Materials; Sustainable Resources; Waste Management; and Green Products. Meanwhile, Water Efficiency considers Water Harvesting and Recycling; and Increase Efficiency. Finally, Innovation looks into Design and Environmental Design Initiatives; and GBI Facilitator.

Similarly, the United States (U.S.) runs the Leadership in Energy and Environmental Design (LEED) as their rating system which is also globally applied (Leadership in Energy and Environmental Design, 2017). In 2009, the organisation published their LEED checklist on Healthcare consisting i) Sustainable sites which include, among others, Construction Activity Pollution Prevention, Environmental Site Assessment and Alternative Transportations; ii) Water Efficiency concerning, among others, Water Use Reduction and Food Waste System; iii) Energy and Atmospheres such as On-site Renewable Energy and Green Power; iv) Materials and Resources including Maintain Existing Walls, Floors and Roof and Construction Waste Management; v) Indoor Environmental Quality such as Outdoor Air Delivery Monitoring and Indoor Chemical and Pollutant Source Contril; vi) Innovation in Design which considers LEED Accredited Professionals among a few other elements; and vii) Regional Priority (Leadership in Energy and Environmental Design, 2017) Bahaudin et al. (2014), who did a comparative study between Malaysia's GBI and several other countries' assessment criteria, posit that the tools are only focusing on finished buildings thus it should also include assessments during the design and planning phases to ensure that minimum externalities occur during the following construction phase. The latter contributes the most negative effects on the environment (Bahaudin et al., 2014; Ikau, Joseph, \& Tawie, 2016). Waste from design phase is caused by, among a few others, lack of experience in construction waste; long project duration; and lack of design information. Meanwhile, waste during procurement is partially caused by the purchase of materials contrary to specification; suppliers' error; and poor schedule of material procurement. Meanwhile, material handling waste is caused by several factors including careless delivery; packaging; inappropriate storage leading to damage; and poor handling instructions. Construction waste, on the other hand, is partly caused by site office waste; errors during construction; vandalism/theft; and rework (Ikau et al., 2016). Apart from that, hospitals' long and continuous operating hours added with poor workmanship on waterproofing installation result in moisture problems and building defects at the ceiling, wall, floor and roof of hospitals (Othman et al., 2015).

Retrospectively, the assessment tools that the Green Building Index (2015) published has already countered his argument. Accordingly, the Non-Residential New Construction (NRNC): Hospitals 2015 is applicable for building owners and developers during the design phase of NRNC or base non-residential building refurbishment; or construction and procurement phase of non-residential building. Improvements in the rating tools are deemed tremendous indicating the government's seriousness in ensuring sustainably green healthcare in Malaysia. Accordingly, Green building is defined as escalating the efficiency of the building's life-cycle resource usage while diminishing its impact on human health and the environment (Green Building Index, 2015). Resource usage revolves around energy, water and materials throughout the designing and operational activities so that its externalities on surrounding is minimised. Green hospitals, on the other hand, is termed as those hospitals that constantly reduces the environmental effects and its contribution to the burden of diseases in running their operations, governance and strategies (Green Building Index, 2015). As the Chairman of Green Building Index Accreditation Panel (GBIAP) puts forward, the public has been aware of green building and green environment, but equal attention on hospital settings are lacking ( $\mathrm{Ng}, 2016)$.

While the success of sustainable development relies heavily on the right to healthy and full-value life that is by nature, which justifies the importance of Ministry of Health $(\mathrm{MOH})$ to participate in the green agenda, it is also important to describe what sustainable development is. Green Hospital Sustainability concerns the integration of design process consisting of planning, implementation and operational buildings that improve the environment, social and economic situations (Setyowati, Harani, \& Falah, 2013). Accordingly, the 2013 Green Technology has contributed $0.8 \%$ to the Gross domestic product (GDP) amounting RM7.9 billion, while creating over 61,000 Green jobs and reduced carbon emission of 11.6 million tonnes CO2 eq/yr (National Transformation Program, 2016). Therefore, with the increased 2018 budget on green technology and tax exemptions as discussed in the following section, it is hoped that the healthcare industry could keep up with the green trend that has been widely adopted in various sectors globally. 


\subsection{Methodology}

Improvement of the healthcare quality in public and private hospitals was emphasised in the 10th Malaysia Plan (Rani, Baharum, Akbar, \& Nawawi, 2015) which this paper is found to be corresponding with. This paper focuses on the green environment policies and practices in Malaysian hospitals in comparison with other countries and why they are important with regards to the internationalisation of the hospitals. The area is chosen due to its lack of comprehensive research in this area. Hence, discussions are presented in the form of critical analysis from past and present research. Information is derived from government reports and conceptual and primary data articles that are mainly from the AcE-Bs, AicE-Bs, AQoL and AicQoL Proceedings which are accessible online in Elsevier's Procedia Social and Behavioural Sciences. Nevertheless, it is realised that the present paper lacks primary data which calls for future research to validate the presented arguments through empirical research.

\subsection{Discussion and Analysis}

\subsection{Green Policy Integration}

In Malaysia, Green policy has been the focus for the government as seen in the incorporation of Green into various government policies. The concept is integrated into the National Key Economic Areas (NKEA) whereby the Economic Transformation Program (ETP) has developed the National Environmental Health Action Plan (NEHAP) which was approved by the Cabinet in 2012 as the agency that caters for Malaysia's focus on the green environment. In fact, the National Transformation Program (2016), in their 2016 Annual Report stated that the government implemented the Large-Scale Solar (LSS) and Net Energy Metering (NEM) in November 2016 to domestic, commercial and industrial consumers as part of the Entry Points Project (EPP) 10: Building Up Renewable Energy and Solar Power Capacity. While healthcare is not directly mentioned, it is fair to assume that the industry should also be actively participating in the national green programmes since the Government targets for 90 MW/year for Peninsular Malaysia and 10 MW/year for Sabah and Labuan in power generation from 2016 until 2020 which requires the participation of households and businesses (National Transformation Program, 2016). Apart from that, there are also stand-alone policies on green such as the National Green Technology Policy (NGTP) established in 2009 that calls for industries, manufacturers and suppliers to provide green products and services as part of their competitive strategy while becoming more environmentally friendly. The policy is run by the Malaysian Green Technology Corporation (GreenTech Malaysia), under the surveillance of the Ministry of Energy, Green Technology and Water (KeTTHA). The NGTP stands on four pillars which are i) Energy - Energy independence and promote efficient utilisation, ii) Environment - Conserve and minimise Impact on the environment, iii) Economy - Enhance the national economic development through the use of technology, and iv) Social - Improve the quality of life for all. These pillars are incorporated into four key Flagship projects which are Green Malaysia Plan, Green Procurement, Electric Mobility and Sustainable Living throughout five sectors namely Energy, Building, Transport, Water Management and Waste Management (Malaysia MyHijau, 2017).

Notably, the NGTP explains that the Energy sector calls for applying Green Technology in power generation in both the supply side management including the industrial and commercial sectors as well as the demand side management programmes. Meanwhile, the Building sector requires the adoption of Green Technology in the construction, management, maintenance and demolition of buildings. On the other hand, the Water and Waste Water Management sector necessitate the industry players to adopt Green Technology in handling the supply, usage and wastage of water management within the business activities. As for the Transportation sector, Green Technology is to be incorporated in the transportation infrastructure and vehicles especially biofuels and public transportation. Hence, it suffices to say that healthcare industry is covered under the NGTP as hospitals also operate at a huge consumption of the five mentioned sectors. Therefore, hospitals should be aware of their operational activities ranging from the energy usage, building the structure, water and waste water management, as well as the transportation activities of staff and patients because they all contribute to greener healthcare. As internationalisation is described as firms adopting international business activities (Cavusgil, 1980), the green healthcare being part of the global efforts should also be incorporated into Malaysian hospitals. This is to ensure that Malaysian hospitals are in line with the international standards of healthcare and green concerns thus attracting more medical tourists into the country due to their confidence in the Malaysian hospitals. This is proven when the Amanjaya Specialist Centre in Kedah, the first Green hospital in Malaysia, also a member of MHTC, is claimed to be able to enhance their patients' health and comfort, improve indoor air quality, reduce carbon dioxide (CO'z) emission and improve water conservation after being GBI-certified (Amanjaya Specialist Centre, 2015). Apart from that, they also hope to achieve low operating and maintenance cost in the long run.

The Government Green Procurement (GGP) is one of the tools to run the NGTP. It is defined as the acquisition of products, services and works that consider the protection criteria and standards of the environment and natural resources while minimising and alleviating the externalities from the business activities (Malaysia MyHijau, 2017). While the 11th Malaysian Plan targeted for 20\% GGP by 2020, its implementation already occurs at 12 ministries and their agencies resulting in growing value of RM482 million GGP, with cumulative Carbon Dioxide emission reductions of 100.431 ktonnes in 2016 (Malaysia MyHijau, 2017). Hence, the top 5 GGP implementing agencies are; i) Ministry of Defense, ii) Ministry of Health, iii) Ministry of Home Affairs, iv) Ministry of Rural and Regional Development and v) Ministry of Urban Wellbeing, Housing and Local Government.

In 2017, GGP implementation has been expanded to all government agencies, requiring them to incorporate green specification in the procurement of twenty GGP product groups including Hotel, Accommodation and Training Centres (Malaysia MyHijau, 2017). While the $\mathrm{MOH}$ is listed in the Top 5 implementing agencies, panel clinics and hospitals for government agencies should also be included into the listed GGP product groups to stress the government concern about the huge environmental externalities that the industry contribute to. Additionally, the Green Building Index Accreditation Panel (GBIAP) reported that hospitals and healthcare facilities are among the 
largest energy-intensive buildings that resulted in massive carbon dioxide emission and various waste materials on the environment $(\mathrm{Ng}, 2016)$ which is also in-line with the World Health Organisation (2015). Nevertheless, despite the 11th Malaysia Plan Thrust of "Pursuing Green Growth for Sustainability and Resilience" regarding structural and non-structural approaches such as innovative food mitigation, green infrastructure and hazard risk maps (National Transformation Program, 2016), these plans are not translated into healthcare and hospital settings. This is so because the Health Facility Planning (HFP) objectives are focusing on providing the appropriate environment and equipment as well as improving health access, quality and safety (National Transformation Program, 2016) but not on the green efforts despite having efficiency and sustainability as their driving forces. Further, the healthcare facilities are only emphasising on the "Improving Wellbeing For All" Thrust of the 11th Malaysia Plan which their initiatives are, among others, mobile healthcare; mobile emergency services; lean management practices in hospitals (through increased capacity and shortened waiting time). Hence, it is seen that MOH's emphasis on green agenda in the healthcare industry is rather low thus it would be fair to assume that the existing GBI-certified hospitals have taken the extra miles to independently shift their business operations to reciprocate to the international preferential standard of having green hospitals.

In the U.S., the environmental policies are run by the United States Environmental Protection Agency (EPA). Accordingly, the Healthcare and Social Assistance sector are entitled to various policies about air, pesticides, waste and water (United States Environmental Protection Agency, 2017). Thus, the Clean Water Act 1972 stresses on, among a few others, reduction of pollutants discharged into waters of the United States and Federal pollution control programs (United States Environmental Protection Agency, 2017). On the other hand, the Clean Air Act (CAA) titled, "Solid Waste Combustion" sets limits for nine pollutants under CAA Section 129 which includes, Cadmium, carbon monoxide, hydrogen chloride, lead and mercury. As for Medical Waste, the EPA is entitled to revise the Hospital Medical Infectious Waste Incinerator (HMIWI) standards in 2013 which leads to an increase in the use of alternative technologies for treating medical waste. Accordingly, EPA also listed several alternatives to handle medical waste including Thermal treatment, such as microwave technologies and Steam sterilization (United States Environmental Protection Agency, 2017). Since healthcare waste contains potentially harmful bacteria, which could infect hospital patients, health workers and the general public (World Health Organisation, 2015), stringent surveillance on waste management is essential to ensure that the hospitals are complying to the green hospital's criteria. As for disinfectants, EPA is to ensure that healthcare operators comply to the Occupational Safety and Health Administration's requirements for Occupational Exposure to blood-borne germs as well as having proper management of any waste when disposed of, which is regulated under the Resource Conservation and Recovery Act (RCRA). Therefore, hospitals are to purchase pesticides with EPA-registered products which have an EPA registration number to it.

Meanwhile, Green Technology (GT) and other green activities are apparent in hospitals from other countries. As for the Children's Hospital of Eastern Ontario (CHEO), Canada, they focused on green procurement through the Green Hospital Procurement Policy and Procedure Manual for Canada (Draft) (Sears \& Bromwich, 2016). Accordingly, this policy puts attention on more energy-efficient products and services, materials and products with higher recycled content and containing materials harvested through organic agricultural practices. Moreover, it also emphasises on materials and products associated with lower content and emissions of hazardous materials and gases, materials and products with longer life-span, suppliers with environmentally-preferable technologies and practices, and environmentally-sustainable or preferable alternatives for commodities (Sears \& Bromwich, 2016).

\subsection{Green Technology Financial Schemes}

Yusof and Jamaludin (2014) reported that financial barriers are among the obstacles to the GT implementation as GT products are deemed expensive and that there is lack of manpower and equipment in GT projects which results in adverse risk takers. Nevertheless, the agenda is reflected in the Federal budget which allocated RM1.5 billion into the Green Technology Financing Scheme (GTFS) in the 2010 budget and increased to RM2 billion between 2013 and 2015 (Green Building Index, 2015). In the recent 2018 Budget, GTFS was allocated RM5 billion (Ministry of Finance, 2017) indicating the government's attention to the environmental sustainability. Meanwhile, the same budget also provides Income Tax Exemption on the Green Sustainable and Responsible Investments (Green SRI) Sukuk Grant up to RM300,000 for sukuk issuer (with a total of RM6 Million) and Tax Exemption on Management Fee Income for Sustainable and Responsible Investment (SRI) Funds to encourage service providers to go green. Moreover, GBI Sdn. Bhd. reported that the government's Green Cost Tax Allowance for GBI-certified buildings are offered between 2013 to 2020 can be offset against $70 \%$ of statutory income during the year of assessment while unutilised amount can be forwarded to the following year (Green Building Index, 2015). Further, Income Tax Exemption for Green Technology Services is also provided for $100 \%$ of statutory income from the year of assessment 2013 to 2020 . Therefore, it is seen that the government plays its role, economically, to encourage goods and service providers to incorporate green procedures into their business operations.

\subsection{Best Practices In Malaysia, US and Canada: Where Should Malaysia Go From There?}

Green Procurement and Green Technology, in fact, have already been implemented in several types of buildings in Malaysia. While proactive management strategy on healthcare facilities has a much stronger influence on patients' satisfaction relative to corrective (Rani et al., 2015), there are various practices being implemented even in different regions of a country. For this article, the GT best practices in multiple types of buildings are categorised into three aspects namely waste and clinical waste management; recycle; and energy efficiency.

Regarding waste and clinical waste management, Malaysia, Omar, Nazli, and Karuppannan (2012) has outlined several Malaysian hospitals' practices on this aspect such as colour-coded waste bins, daily collection and transportation of clinical waste and temporary central storage for clinical waste before final disposal. Nevertheless, it is also found that there is lack of instructions on the clinical waste segregation and practices as well as the mix of clinical waste with general waste. Meanwhile, in the hospitality industry, waste separation 
program and food and waste compost are among the highly applied waste reduction management programme in Malaysian green hotels and resorts as empirically studied by Yusof and Jamaludin (2013).

On the other hand, recycling can provide huge positive impacts to the environment. The Fukuoka Prefectural International Hall in Japan practices Green Façade glass wall which materials are recyclable (Farid, Ahmad, Raub, \& Shaari, 2016). The Amanjaya Specialist Centre has a recycling water system derived from rainwater and air-con condensate water for irrigation which significantly saves water (Amanjaya Specialist Centre, 2015). Moreover, The Putrajaya Energy Commission practices the Grey Water Recycling in the irrigation system as part of their Green Façade efforts (Farid et al., 2016). While green façade is said to be a passive approach to sustainable design (Othman \& Sahidin, 2016), its contribution to at least reduce the building temperature thus serving as active air conditioning unit (Davis, Ramirez, \& Pérez, 2016). Recycling is also doable in building materials as exemplified through the use of sustainable façade is also applied in the Manuel Gea Gonzales Hospital, Mexico City with the sub-tropical weather which reduces air pollution, improves indoor air quality and increases the building market value. (Farid et al., 2016). While recycling is found to be hugely practised by many, findings on hospital buildings are deemed insufficient thus strengthening the urgency to enforce and overview the activities

Meanwhile, energy efficiency at the Orthopaedic Hospital of Professor Dr. R. Soeharso in Surakarta, Indonesia implements the Solar Cell System, Inverter Air Conditioning System, and natural lighting to reduce the dependency on Indonesian electricity power and generators (Setyowati et al., 2013). As for Malaysia, the Amanjaya Specialist Centre installed a Solar Photovoltaic (PV) system which generates electricity without greenhouse gas emissions and hence avoiding contribution to global warming. The green technology provides many benefits including enhancing occupants' health and comfort, improving indoor air quality, reducing Carbon dioxide emission and minimising maintenance and operating cost (Amanjaya Specialist Centre, 2015). Conclusively, GT has relatively low demand due to the lack of understanding about its products and services, lack of experts along the value chain and difficulty in balancing service quality with environmental performance (Yusof \& Jamaludin, 2014). Moreover, hospital operators give low priority over the various initiatives as there are only eleven GBI-certified hospitals, as of August $2016(\mathrm{Ng}, 2016)$.

\section{0 Conclusion}

Therefore, despite the similarities between the international rating tools and GBl's six main criteria for Hospital Green Building rating, it is seen that the commonly applied green activities are recycling and adopting energy-efficient appliances in the hospital building to ensure that the premises adhere to the Green assessment tools. Hence, with the relatively low emphasis on green agenda by the $\mathrm{MOH}$, Malaysian hospitals have a long way to go to be in line with the international hospitals' standards and quality of green healthcare. As internationalisation requires service firms to reach the international standard of services to meet the international reputation, Malaysian hospitals must seriously consider the green agenda into their internationalisation activities as it stands a strong point in their internationalisation performance and the green agenda should be perceived as contributing towards a holistic life development promoted by Bakar et al. (2016). In view of the idea that the environmental behaviour that is reflected by Malaysians is caused by cost-saving rather than their environmental awareness Mei et al. (2016), it is hoped that this paper sparks the urgency for the creation of clear, exact and feasible policies on green agenda for public and private hospitals in response to the global calls for green hospitals apart from being competitively advantaged in internationalising their healthcare services.

\section{Acknowledgements}

The authors would like to thank the Ministry of Higher Education Malaysia for the financial support through the Fundamental Research Grant Scheme (FRGS), File No: 600-RMI/FRGS 5/3 (36/2015) and the Research Management Centre, Institute of Research Management \& Innovation (IRMI) Universiti Teknologi MARA, Shah Alam for managing the fund.

\section{References}

Amanjaya Specialist Centre. (2015). Green Hospital. Retrieved from https://www.amanjayasc.com/green-hospital

Bahaudin, A. Y., Elias, E. M., \& Saifudin, A. M. (2014). A comparison of the green building's criteria. Paper presented at the E3S Web of Conferences.

Bakar, A. A., Osman, M. M., Bachok, S., \& Ibrahim, M. (2016). Investigating Rationales of Malaysia Quality of Life and Wellbeing Components and Indicators. Procedia Social and Behavioral Sciences, 222, 132-142.

Cavusgil, S. (1980). On the internationalization process of firms. European Research, 8, 273-281.

Davis, M. J. M., Ramirez, F., \& Pérez, M. E. (2016). More than just a Green Façade: Vertical Gardens as Active Air Conditioning Units. Procedia Engineering, 145, 12501257. doi:https://doi.org/10.1016/j.proeng.2016.04.161

Farid, F. H. M., Ahmad, S. S., Raub, A. B. A., \& Shaari, M. F. (2016). Green "Breathing Facades" for Occupants' Improved Quality of Life. Procedia - Social and Behavioral Sciences, 234, 173-184. doi:https://doi.org/10.1016/j.sbspro.2016.10.232

Green Building Index. (2015). GBI NRNC: Hospital V1.0: Green Building Index Sdn Bhd.

Ikau, R., Joseph, C., \& Tawie, R. (2016). Factors Influencing Waste Generation in the Construction Industry in Malaysia. Procedia - Social and Behavioral Sciences, 234, 11-18. doi:https://doi.org/10.1016/j.sbspro.2016.10.213 
Leadership in Energy and Environmental Design. (2017). LEED is green building. Retrieved from https://new.usgbc.org/leed

Malaysia MyHijau. (2017). Who We Are. Retrieved from https://www.myhijau.my/who-we-are/

Mei, N. S., Wai, C. W., \& Ahamad, R. (2016). Environmental Awareness and Behaviour Index for Malaysia. Procedia - Social and Behavioral Sciences, 222, 668-675.

Ministry of Finance. (2017). 2018 Budget. Kuala Lumpur: Percetakan Nasional Malaysia Berhad.

National Transformation Program. (2016). National Transformation Program Annual Report 2016.

$\mathrm{Ng}$, A. (2016, July 13th). Sustainable Agenda: Healthcare operators urged to go green. Star Property.

Omar, D., Nazli, S. N., \& Karuppannan, S. A. L. (2012). Clinical Waste Management in District Hospitals of Tumpat, Batu Pahat and Taiping. Procedia - Social and Behavioral Sciences, 68, 134-145. doi:https://doi.org/10.1016/j.sbspro.2012.12.213

Othman, A. R., \& Sahidin, N. (2016). Vertical Greening Façade as Passive Approach in Sustainable Design. Procedia - Social and Behavioral Sciences, $222,845-854$. doi:https://doi.org/10.1016/j.sbspro.2016.05.185

Othman, N. L., Jaafar, M., Harun, W. M. W., \& Ibrahim, F. (2015). A Case Study on Moisture Problems and Building Defects. In M. Y. Abbas (Ed.), Asian Conference on Environment-Behaviour Studies (Vol. 170, pp. 27-36).

Rani, N. A. A., Baharum, M. R., Akbar, A. R. N., \& Nawawi, A. H. (2015). Perception of Maintenance Management Strategy on Healthcare Facilities. Procedia - Social and Behavioral Sciences, 170, 272-281. doi:https://doi.org/10.1016/j.sbspro.2015.01.037

Sears, M., \& Bromwich, M. (2016). Green Hospital Procurement Policy and Procedure Manual, and Implementation Guide (Draft).

Setyowati, E., Harani, A. R., \& Falah, Y. N. (2013). Green Building Design Concepts of Healthcare Facilities on the Orthopedic Hospital in the Tropics. Procedia - Social and Behavioral Sciences, 101, 189-199. doi:https://doi.org/10.1016/j.sbspro.2013.07.192

United States Environmental Protection Agency. (2017). Regulatory Information by Sector: Healthcare and Social Assistance Sector (NAICS 62). Retrieved from https://www.epa.gov/regulatory-information-sector/healthcare-and-social-assistance-sector-naics-62

World Health Organisation. (2015). Healthcare Waste. Media Centre. Retrieved from http://www.who.int/mediacentre/factsheets/fs253/en/

Yusof, Z. B., \& Jamaludin, M. (2013). Green Approaches of Malaysian Green Hotels and Resorts. In M. Y. Abbas (Ed.), Ace-Bs 2013 Hanoi (Vol. 85, pp. 421-431).

Yusof, Z. B., \& Jamaludin, M. (2014). Barriers of Malaysian Green Hotels and Resorts. Procedia - Social and Behavioral Sciences, 153, 501-509. doi:https://doi.org/10.1016/j.sbspro.2014.10.083 